\section{결핵의 예방적치료}

\section{Chemoprophylaxis for the Prevention of Tuberculosis}

Am. Rev. Res. Dis.

Vol. 104, No. 3, 460-465, 1971

American Thoracic Society, National Tuberculosis and Respiratory Diseases Association 및 Canter for Disease Control 의 공동성명.

이 성명은 1967년 9월에 간행된 결핵예방을 위한 화 학예방 “Chemoprophylaxis for the prevention of Tuberculosis”을 개정한 것임.

항결핵제 들은 결핵치료에 광명을 가져온 것뿐 아니라 감염된 사람들의 발병예방에도 효율적으로 사용된다.

예방적치료(화학예방)는 약을 복용하는 사람의 치유 된 또는 $\mathrm{X}$ 선상으로 볼 수 없는 병소속의 균을 제거함으 로서 이루어진다.

임상적으로 결핵을 예방함에 있어서 $\mathrm{INH}$ 의 가치를 인정할수 있는 확실한 과학적 논거들이 있다. 미국 공 중보건당국에 의한 광범위한 실험에 의하여 치료군에 있어서 화실히 발병율이 감소하는 것을 알수있다.

발병위험군(high sick group)에 있어서 $50 \% \sim 75 \%$ 의 발병예 방을 기대한다는 것은 타당하다고 본다.

전 미국에 있어 광범위하게 예방치료를 시행한다면 앞으로 15 년간에 미국전체환자수를 30 만명으로 줄일수 있다.

\section{예방치료에 사용한 약품}

보통 INH 단독 어른 1 일량 $300 \mathrm{mg}$, 소아에게는 1 일 $100 \mathrm{mg} / \mathrm{kg} \mathrm{BW}$ 쵝고 $300 \mathrm{mg}$ 까저를 1 희에 복용 12 개월간 계속함 이 이상의 분량이나 기간은 필요치않다. 예방치 료를 위하여 INH 를 복용중인 사람들중에 간기능장해를 이르키는 사람이 늘어난다고 보고되고 있지만, 이것은 예기할수 없는 과민성반응으로 믿어지고 있으며 약간의 예외를 제외하고는 대부분의 경우 치료개시후 3 개월이 내에 발생하였다. 약의 부작용으로 간주되는 중세를 발 견했을때 투약을 중지하므로서 불뢔한 반응은 없어진다 다만 알아두어야 할것은 $\mathrm{INH}$ 와 관련된 간장질환이 일 어날수 있는 기회는 복약중인 1년간인데 비하여 활동성 결핵의 발병할수 있는 기회는 일평생이라는 점이다.

이미 결핵균에 감염된 사람에게 INH 복약을 권고하는
이유가 바로 이점이고 또 결과적으로는 결핵의 전염을 막는데 있다. 공중보건당국의 조사에 의하면 발병위험 군에 1년간의 예방치료를 끝마친후에도 장기간 예방효 과가 계속된다고 한다. 기왕에 예 방치료를 받은 군을 15 년간 관찰한 결과 지연반응(부작용)은 보지 못하였다.

예방치료대상

모든 Tuberculin 양성 자는 활동성결핵 발병의 위험성 이 약간은 있다. 그러므로 만투반응(PPD5Tu)에 $10 \mathrm{~mm}$ 이상으로 반응하는 모든사람은 예방치료로서 혜택을 받 을수 있다. 그러나 전주민을 검사하고 양성자 전부를 치 료한다는 것은 현실적이 못됨으로 공중보건의 입장에서 발병의 위험성이 많은 대상을 선택해야 할것이다. 즉 특히 어린이를 포함하여 다른사람에게 전염시킬 가능성 자원 예산등을 고려해서 결정지을 것이다.

다음에 열거한 대상중 처음 6 개의 대상은 특히 예방 치료를 필요로 하는 대상들이고 5,6 번을 제외하면 우선 권을 주어야 할 순서대로 되어있고 각각 발병의 위험도 를 표시했다.

1. 환자가족(접촉자)로서 Tuberculin 양성자 및 음성 자(특히 어린이)(Index Case 를 발견한지 약 1년간에 발병할수 있는 위험도는 30 명중 1 명이다.)

2. 최근 양전된자(연령불구)

(위험도는 30 명중 1 명)

3. 과거에 충분한 화학요법을 받지 않은 결핵환자로서 현재 비 활동성인자(연간 위험도는 75 명중 1 명)

4. $\mathrm{T}$ 반응 양성이고 $\mathrm{X}$ 선상 이상음영이 있는 사람 (연간 발병위험도는 125 명중 1 명)

5. 20세미만의 $\mathrm{T}$ 반응양성 자

이들은 평생 발병가능성이 있으며 특히 어린이와 10 대소년은 당장에 발병할 가능성이 높다.

6. 다음에 열거한 바와 같은 임상적으로 특별한 환경 에 있는 자중 $\mathrm{T}$ 반응양성자, 이는 특별한 환경에 처해있 을 동안에 한하여 해당되며 그 위험도도 각각 다르다.

7. 기타(위에서 지적한 이외의) $\mathrm{T}$ 양성자(연간 위험 도는 1,400 명 중 1 명)

\section{환자가족접촉자}

최근에 발견된 신환자나 재발환자의 접촉가족은 발병 될 가능성이 높다. 이들은 곧 검진을 받아야하며 만일 활동성결핵으로 진단되면 곧 보고해야 하고 병합치료를 받아야 한다.

이들 접촉자들은 $\mathrm{T}$ 반응이 $10 \mathrm{~mm}$ 이하라도 예방치 료를 받아야 한다. 만투반응에 경결이 $5 \mathrm{~mm}$ 이상인자는 12 개월간 완전히 투약해야 한다.

이런경우 반응이 $5 \sim 9 \mathrm{~mm}$ 이라 할지라도 이것은 
Atypical mycobacteria 의 감염으로 인 한 Cross reaction 보다는 결핵균에 폭로된 결과일 가능성이 더 크다. 경 결 $5 \mathrm{~mm}$ 이하의 음성자의 경우 그들이 환자와 최종적으 로 접촉한 후 3 개월이 되었을때 다시 검사해야 한다. 만일 환자와의 접촉이 확실이 꼻어졌고 $\mathrm{T}$ 반응이 계속 음성이라면 예방치료를 중단 할수도 있다.

그러나 환자와의 접촉이 계속된다면 계속되는 동안 예방치료도 계속하는 겻이 좋다.

밀집된 집단에 환자가 유행하거나 또는 정규적으로 음성자에 대한 $\mathrm{T}$ 반응 재검사가 불가능한 경우도 예방 치료를 권한다.

최근양전 된자(연령불구)

최근 양전된자라 함은 2 년이내에 $\mathrm{T}$ 반응이 $10 \mathrm{~mm}$ 미 만에서 $12 \mathrm{~mm}$ 이상으로 커졌고 커진차이가 $6 \mathrm{~mm}$ 이상 인 경우를 말한다.

예를들면 먼저 반응이 $8 \mathrm{~mm}$ 이었던 사람이 그다음해 에 $12 \mathrm{~mm}$ 로 커졌을 경우 이는 양전으로 보지 않으며 만 일 $8 \mathrm{~mm}$ 에서 $14 \mathrm{~mm}$ 로 되었을때 양전으로 해석한다.

\section{비활동성결핵}

과거에 결핵으로 진단되었으나 충분한 화학요법을 받 지않고 현재도 비활동성인자 또는 현재 $\mathrm{X}$ 선상 치유된 성인타입의 병집이 있고 $\mathrm{T}$ 반응양성이며 화학요법을 받 은 일이 없는자.

치료를 받지않은 비활동성결핵으로 부터 재발되는 율 은 연간 $1.0 \sim 4.7 \%$ 에 달한다. 보건당국에 등록되어있 는 이런 사람들의 기록을 검토하고 예방치료롤 할 것인 지 여부를 분석한다는 것은 매우 가치가 있는 일이다. 지역사희인구 전체를 조사하는것 보다는 이런 집 단에 손을 뻗는것이 보다 더 현실적이다.

임상적으로 톡별한 환경에 있는자

$\mathrm{T}$ 반응양성자중 임상적으로 특별한 환경에 있을때에 는 발병 또는 재발의 위험성이 크며 과거 $\mathrm{INH}$ 치로 유 무를 막론하고 예방치료를 받아야 한다.

이런 특별한 환경이란 (1) adrenal corticoid 또는 immuno suppresive 치료 (2) gastrectomy 후 (3) leu kemia 나 Hodgkin's disease 와 같은 reticuloeudothelial disease (4) 중중당노병의 불안정시기 (5) 규페 (6) 과 거치료력이 없는 비활동성결핵인 임신부 또는 $T$ 선상 계속 비활동성인 임신부는 분만 3 개월전부더 시작해서 1 년간 예방치료를 받아야 한다.

과거에 치료를 받은 일이 있는 $\mathrm{T}$ 양성인 어린이로서 홍역 백일해에 걸렸거나 홍역예빙주사를 맞을 깅우 8주 일간 예방치료를 할것 만일 과거치료력이 없을 경우 예 방치료는 12 개월로 연장해야 한다.

\section{0세미만의 $\mathrm{T}$ 반응양성자}

취학전의 어린이로서 $\mathrm{T}$ 반응양성 일 경우 예방치료는 필수적이며 10대소년인 경우에도 우선적으로 고려해야 할 것이다. 두경우 다 발병의 위험도가 높을뿐 아니라 만일 발병했을 때에는 중한 합병중이 많다. 또한 이들 의 발병가능성은 평생동안이라 생각되는 이만큼 예방치 료는 그들이 양성이라는 것을 알았을때 즉시 시작할 것 이다.

\section{기타의 양성자}

이 부류에 속하는 것은 $\mathrm{X}$ 선상 정상인 모든 양성자를 말한다.

예방치료를 고려함에 있어 그사람이 전염성환자가 되 었을 경우를 생각할것. 예를 들어 감수성인 사람이 많 이 기거하는 선박내 또는 학교 교실등 밀집한 환경하에 있는 양성자를 우선적으로 고려해야 할것이다.

\section{예방치료사업의 설정(실천)}

예 방치료사업은 다음 두가지 길에 의하여 광범위하게 실천할수 있을 것이다.

1. 의사개인적으로 결핵발병의 위험성이 많은 사람들 을 개별적으로 예방치료 할수 있을 것이다.

2. 지역기관이(지방자치단체) 그지역의 보건사업의 일환으로서 발병 위험도가 높은 인구군에 대하여 예방치 료계획을 세울수 있다. 대부분의 경우 이런 인구군은 환자접촉자기록 또는 환자발견사업기록등에 의하여 보 건당국에 알려져 있다. 예방치료를 하기위하여 일부러 일반주민의 $\mathrm{T}$ 반응검사를 할 필요는 없다. 다만 다음에 열거하는 예방치료대상자를 확정하기 위한 방법일때는 제외된다.

\section{선택과정}

예방치료를 위하여 INH 를 투여하기 전에 다음의 선 택과정을 (정밀검사) 거쳐야 한다.

1. 활동성결핵의 제외

모든 대상 $\mathrm{T}$ 양성자는 횽부 $\mathrm{X}$ 선촬영하고 만일 $\mathrm{X}$ 선 상 페결핵과 같은 소건이 있을경우 임싱적평가, 세균학 적검사, 과거 $\mathrm{X}$ 선소견과의 비교등 활동성결핵이 아님 을 확인하기 위한 조사가 필요하다. 이것은 활동성결핵 인 경우 예방치료 보다는 더 강력한 치료가 필요하기 때문이다.

2. 과거치료자를 제외하기 위한 INH 복약 유무에 관 한 질문

(단 앞세 언급한 임상적 특렬한 환경에 있을 경-우 제 외)

3. INH 에 대한 과민반응자를 제외하기 위하여 과거 부작웅유무에 관한 질문 
4. 환자 개개인의 특별한 조정을 하기 위한 것으로 현 재 diphenylhydantoin, meprobamate, steroid 등 복약 중인지 여부 질문

5. 간장질환의 급성기를 피하기 위하여 현재 증세 유 무, INH 로 인한 간장장해는 예기하기 어려운 과민성 반 응으로 믿어지기 때문에 과거에 INH와 관계없는 간장 질환이나 만성간장질환은 INH 예방치료의 금기조항은 되지 않는다.

$\mathrm{INH}$ 와 관련된다고 알려진 간장질환인 경우라도 의사 는 환자의 결핵발병위험도, 타인 특히 어린이에 대한 전 염가능성, 간장질환자체의 경증, 환자의 신뢰도 등등을 감안하여 1 년간의 예방치료가 필요한지를 개별적으로 결정지어야 할것이다.

\section{환자의 설득과 격려}

환자를 충분히 설득시킴으로서 대부분의 경우 전기간 잘 복약한다. 의사, 간호원, 기타 보건요원들의 성의와 격려 여하에 달려있다.

예방치료를 시작할 때 의사는 환자 또는 환자의 보호 자를 교육시키고 설득하는데 시간을 아껴서는 안된다. 간호원과 보건요원도 계속적으로 설득해야 한다. 정규 적으로 환자의 가정, 사무실, 담당진료소등을 방문하거 나 전화연락등으로 꾸준히 교육시켜야 한다. 다음과 같 은 INH 부작용과 관련있는 증상이 없는지 매월 문의 하 여야 한다.

1. 식욕감퇴, 피로, 불쾌감등 간장손상의 증세(자각 증)

2. 코피색, 다색등으로 표현되는 암색뇨, 혹탁뇨, 황 달, 강막(翚膜)부증등의 간장손상의 중후(타각증)

이상과 같은 증세 또는 소견이 있을 경우 즉각적으로 복약을 중지하고 의사와 상의하여야 한다. 이런 중세 나 소견이 없는 한 정규적인 간기능검사(SGOT, SGPT, LDH. TSB, Alkaline phosphatase)는 필요 없다.

환자에게 일개원분씩 투약하므로서 휜자의 메월 접촉 할 수 있을 것이다 한가족중 두사람이상 복약하는 경우 책임질만한 사람에게 투약 시초 충분히 설명해서 다른 가족들에 관한 이상유무도 곧 알 수 있게 하는 것이 좋다

환자들이 매일 잊어버리지 않고 약을 잘 먹기위한 방 법에 대해서 조언해 주어야 한다. 병원에 다니거나 약 을 타는데 있을 수 있는 지장을 없애주어야 한다.

\section{의 료기관내의 결핵관리사업(요약)}

(환자들의 세부적 설명은 결핵의 예방치료와 같음으 로 생략함.)

취급하는 모든 의료기관내의 결핵관리사업은 주로 종업원을 보호하기 위한 것이지만 다른 동료환자들을
보호한다는 점에서도 뽁같이 중요하고 또 효율적으 로 잘 계획된 사업이라면 결핵관리사업의 시범적인 교 육자료가 된다.

모든 의료기관은 이 사업에 필요한 자금을 내놓을 책 임이 있으며 책임의사를 두어야 하고 $\mathrm{T}$ 반응검사를 할 훈련된 간호원과 기록보존을 위한 실무자가 필요하다. 의료기관내의 결핵관리사업은 다음 두가지 방향이 있다.

(1) 감염자 발병자의 조기발견

(2) 감염 방지책

\section{감염자발견}

모든 종업자, 의과대학학생 학생간호원등의 취업시 또는 입학시에 X선직촬, Tuberculin 반응이 필요하다. $\mathrm{T}$ 양성자에 대하여는 호흡기 이외의 결핵등도 상세히 검사해야 한다. $\mathrm{T}$ 반응에 $15 \mathrm{~mm}$ 이상인자는 특히 예 방치료가 필요하다.

모든 예방치료자는 6 개월후에 추구 $\mathrm{X}$ 선촬영이 필요 하고 다음에는 매년 한번씩 촬영한다. 만일 대상자로서 예방치료에 응하지 못할 경우 매 3 개월마다 $\mathrm{X}$ 선촬영하 고 다음 2 년간은 6 개월마다 그후에는 매년 1 회 촬영한 다. $\mathrm{T}$ 음성자는 $6 \sim 12$ 개월 간격으로 $\mathrm{T}$ 반응검사 한다.

$\mathrm{T}$ 반응양전자 최근에 양전된 사람은 세밀한 진단 이 필요한 것은 물론 전염원을 찾기 위하여 그가족에 대 한 검사가 필요하다. 간단히 병원에서 감염 되었다고 단정해서는 안된다. 양전자로서 명확한 발명의 증후가 없을 경우 예방치료를 해야한다.

여러 조사에 의하면 양전된지 $2 \sim 3$ 년간에 양전자의 $12 \%$ 까지 발병한다고 한다.

\section{감염방지}

감염을 방지하기 위하여 철저한 전염원의 색출이 필 요하다. 이미 진단이 확실한 환자 보다 일반병실의 환 자 사이에 숨어있는 아직 진단이 안된 환자로 부터 전염 되는 경우가 많다는 것을 알아야 한다.

기첨을 하거나 담을 뺕는 활동성환자에 대한 철저한 관리가 필요하다. 공동도 없고 기침도 안하는 활동성 결핵환자로서 정규적으로 검사를 받을 동안은 격리할 필요는 없다.

$\mathrm{T}$ 음성자인 종업원이 균양성 환자와 접촉할 경우 처 음 및 $6 \sim 12$ 주후에 다시 $\mathrm{T}$ 반응검사를 해야한다.

드믄 경우이긴 하겠지만 만일 심각한 접촉이 있었거 나 상처를 통해서 균이 체내에 들어갔다고 인정되면 즉 시 $\mathrm{INH}$ 투약을 하고 3 개월후에 의사의 판단에 의하여 감염되지 안했거나 발병되지 않았다고 인정되면 투약을 중지한다. (의장 Damald L. Bruminer 외 8명이 서명함) (초역자:송 달 호) 